Original Article

\title{
Effect of Combined Heat killed Probiotic and Wheat Bran on Gastrointestinal Symptoms in Hemodialysis Children.
}

\author{
Doaa Mohammed Youssef, Ali Mohammed Abo Zeid, May Abd Alfattah Neemat-Allah, \\ Yasmeen Ghanem Zakaria , Aly Abdel-Rahman Yousef, Seham Mohamed Ramadan \\ Pediatrics Department- Faculty of medicine - Zagazig University
}

\begin{abstract}
Introduction

Gastrointestinal (GIT) disturbances are recorded in patients with end stage renal diseases (ESRD) frequently, killed probiotic was reported in to decrease GIT problems many other diseases ; So The aim of our study is to evaluate whether a combination of heat killed probiotic and wheat bran affect the presence and severity of gastrointestinal symptoms (GIS) in hemodialysis children
\end{abstract}

Patients and methods

Our study was Open label uncontrolled clinical trial conducted on 35 pediatric patients on regular hemodialysis for end stage renal disease. Every patient received one sachet of killed probiotic and wheat bran twice daily for two months. Assessment of GIT symptoms were done one month before administration of the drug, then follow them for two months during intervention then reassess the symptoms.

\section{Result}

We found that combined heat killed probiotic + wheat bran administration to hemodialysis children produced significant differences in urea, $\mathrm{Hb}$ and $\mathrm{Po} 4$ levels compared to baseline levels, in addition children produced highly significant decrease in all gastrointestinal symptoms $(\mathrm{P}<0.001)$ after 1 month, after 2 months in comparison to baseline.

\section{Conclusion}

We concluded that combination of heat killed probiotic and wheat bran decreases presence and severity of gastrointestinal symptoms (GIS) in hemodialysis children; thus we hypothysed that, our results could represent an important preliminary work that need further justification.

\section{Key words}

Probiotic, abdomen, chronic, children, renal

\section{Correspondence}

Doaa Mohammed Youssef

Faculty of Medicine, Zagazig University

Email: Dody5176@yahoo.com

ORCID No: 0000-0001-9948-5690

\section{geget : The Journal of the Egyptian Society of Pediatric Nephrology and Transplantation (ESPNT) geget https://geget.journals.ekb.eg/ \\ Published by ESPNT http://espnt.net/ \\ Cohosted by Egyptian Knowledge Bank https://www.ekb.eg}




\section{Introduction}

Patients with almost all renal disease usually have impaired intestinal microbiome. It is suggested that almost two thirds of individuals with uremia have abnormalities in the gastrointestinal mucosa and a disequilibrium in the intestinal ecosystem [1]. The incidence of GI symptoms can largely be attributed to the underlying conditions, such as increased level of uremic toxin, the effect of dialysis, lifestyle change, or the medications required for treatment [2], the most common gastrointestinal symptoms in patients with renal failure include nausea, vomiting, abdominal pain, constipation, and diarrhea [3].

The term of probiotic was derived from Greek, meaning "for life". The joint Food and Agriculture Organization (FAO) and World Health Organization (WHO) Expert Consultation on evaluation of health and nutritional properties of probiotics in food including powder milk with live lactic acid bacteria defined probiotics as: "live microorganisms that, when administered in adequate amounts, confer a health benefit on the host" [4]. Prebiotics have the ability to support the growth of Probiotics [5]. It is believed that diets high in phytate contribute to Fe deficiency [6]. In contrast, some naturally occurring non-digestible oligosaccharides in wheat, known as prebiotics, have been suggested to have an enhancing effect on Fe absorption [7].

Studies have demonstrated that heat-killed probiotics are safer than live probiotics for purposes such as eliminating antibiotic resistant genes, preventing production of recombinant strains, controlling the microbial load during probiotic supplementation, and application in children and immunosuppressed patients [8],[9], Equal effectiveness of viable and heat-killed Lactobacillus rhamnosus GG [10] and greater efficacy of heat-killed Lactobacillus acidophilus LB than viable non-specified strain of $L$. acidophilus [11], for the treatment diarrhea were noted. It was further denoted that application of inactivated cells may be a safer approach than using live microbes in premature infant immediately after birth or in immuno-suppressed individuals [12].

The aim of our study is to evaluate whether a combination of heat killed probiotic and wheat bran affect the presence and severity of gastrointestinal symptoms (GIS) in hemodialysis children

\section{Patients and methods}

Patients Our study was Open label uncontrolled clinical trial conducted on 35 pediatric patients aged 10-18 years there were 17 males and 18 females, they are all on regular hemodialysis for end stage renal disease (ESRD), in Pediatric Nephrology Unit, Zagazig University. The study was conducted after taking an informed consent from patient and /or their parents, 35 out of 54 on patients on hemodialysis accept to participate in our study, We included pediatric patients clinically stable on regular hemodialysis with arteriovenous fistula, duration of dialysis was $7.37 \pm 2.921$ years and receiving thrice-weekly hemodialysis for at least 3 months before start the study. In this study we excluded Patients with usual intake of Probiotics, omega-3 fatty acids, Patients with immunosuppressive and/or non-steroidal antiinflammatory drugs and Patients with medical illnesses that affect nutritional and inflammatory status (cancer, decompensated heart failure, chronic liver diseases, intestinal malabsorption, active infections, and acquired immunodeficiency syndrome)

Methodology All Studied infants were subjected to the following at the beginning of the study; Full detailed history taking including; Personal history (age, sex, address), Compliant, Present history including and GIT symptoms (Anorexia, Nausea, Vomiting, Heart burn,gastric discomfort, gastric distention, constipation, diarrhea, Complication related to other systems and Drugs given). We also toke past history; History of causative diseases, Duration of dialysis and Family history. Thorough clinical examination was done including the following; General examination, Anthropometric measurements and local examination. Routine laboratory investigation were done to all patients pre-dialysis including (urea, $\mathrm{Hb}$, CRP and Po4). All patients received the same dose of iron and Erythropoietin before and after using the probiotic

Daily intake of Probiotics, patients received standard dose of (Lacteol forte) twice daily starting with the first day of the study till complete 2 months and receive also one wheat bran capsule twice daily as a source of insoluble fiber]. Lacteal forte was used in the form of sachets product by the company of the tenth of Ramadan/Egypt with a license from the French company Axcan Pharma-France. each sachet contains Lactobacillus LB, corresponding to lactobacillus delbruekii and lactobacillus fermentum one sachet containing 10 billion of lyophilized heat-killed L. acidophilus LB, twice daily plus one capsule of wheat bran starting with the first day of the study till two months later; The main action of Lactobacillus $L B$ consist in stimulating and regulating the intestine's host defense mechanisms.

Every patient received also Wheat bran as a concentrated source of insoluble fiber may result in synergistic effects on gastrointestinal function, in the form of capsules each capsule contains Bran (treated) $400 \mathrm{mg}$ product by the company of Arab Company for pharmaceuticals and medicinal plants (MEPACO).

Assessment of GIT symptoms were done before administration of the drug, then follow them for two months during intervention with reassessment of the symptoms table 1 . 
Table 1: Questionnaire design of GIT symptoms.

\begin{tabular}{|c|c|c|c|c|c|}
\hline Symptoms & None & Mild & Moderate & Severe & Very Severe \\
\hline Anorexia & 1 & 2 & 3 & 4 & 5 \\
\hline Nausea & 1 & 2 & 3 & 4 & 5 \\
\hline Vomiting & 1 & 2 & 3 & 4 & 5 \\
\hline Gastric discomfort & 1 & 2 & 3 & 4 & 5 \\
\hline Abdominal distention & 1 & 2 & 3 & 4 & 5 \\
\hline Constipation & 1 & 2 & 3 & 4 & 5 \\
\hline
\end{tabular}

None $=$ absence of symptom $/$ Mild $=$ presence of symptom, but no effect of daily living/

Moderate = obvious symptom, with slight effect on daily living / Severe = severe symptom, with great effect on daily living /

Very severe $=$ outstanding symptom hardly endurable [12].

\section{Statistical analysis}

Data were analyzed by Statistical Package of Social Science (SPSS) version 17, we used Wilcoxon SignedRank Test as nonparametric alternative to paired t-test is used to compare two sets of data that come from the same participants and we used Paired-samples t-test (dependent t-test) to compare the means between two related groups on the same continuous, dependent variable. We used Friedman test to test differences between groups when the dependent variable being measured is ordinal (One group is measured on three or more different occasions). $\mathrm{P}$ value was considered significant if less than 0.05 .

\section{Results}

Clinic-demographic data We found that combined heat killed probiotic +wheat bran administration to hemodialysis children produced significant differences in urea, $\mathrm{Hb}, \mathrm{CRP}$ and $\mathrm{Po}_{4}$ levels compared to baseline levels. However, other clinic-laboratory parameters showed no significant differences following combined heat killed probiotic+ wheat bran administration compared to baseline levels (table 2).

Effect of using heat killed probiotic and wheat Combined heat killed probiotic + wheat bran administration to hemodialysis children produced highly significant decrease in all gastrointestinal symptoms $(P<0.001)$ after 1 month, after 2 months in comparison to baseline (table 3 , figure 1). 
Table 2: Comparison between clinic-laboratory data among the studied children (before and after combined heat killed probiotic and wheat bran administration).

\begin{tabular}{|c|c|c|c|c|}
\hline \multirow{2}{*}{ Variables } & $\begin{array}{c}\text { Before } \\
\text { ( probiotic +wheat bran) }\end{array}$ & $\begin{array}{c}\text { After } \\
\text { (probiotic +wheat bran) }\end{array}$ & \multirow{2}{*}{ Test } & \multirow{2}{*}{$P$-value } \\
\hline & $n=35$ & $n=35$ & & \\
\hline $\begin{array}{c}\text { Weight }(\mathbf{K g}) \\
\text { Mean } \pm \text { SD } \\
\text { Median (Range) }\end{array}$ & $\begin{array}{l}32.61 \pm 6.26 \\
32(21-43)\end{array}$ & $\begin{array}{l}32.81 \pm 6.01 \\
31(21-43)\end{array}$ & $\begin{array}{c}\text { Wilcoxon signed } \\
\text { rank test }(\mathrm{Z})= \\
1.357\end{array}$ & 0.175 \\
\hline $\begin{array}{c}\text { Albumin }(\mathrm{mmol} / \mathrm{L}) \\
\text { Mean } \pm \text { SD } \\
\text { Median (Range) }\end{array}$ & $\begin{array}{l}4.13 \pm 0.260 \\
4.1(3.7-4.6)\end{array}$ & $\begin{array}{c}4.14 \pm 0.19 \\
4.2(3.7-4.4)\end{array}$ & $\begin{array}{c}\text { Wilcoxon signed } \\
\text { rank test }(\mathrm{Z})= \\
0.205\end{array}$ & 0.837 \\
\hline $\begin{array}{c}\text { Urea }(\mathrm{mg} / \mathrm{dl}) \\
\text { Mean } \pm \text { SD } \\
\text { Median (Range) }\end{array}$ & $\begin{array}{l}53.68 \pm 10.97 \\
53.4(7.3-66)\end{array}$ & $\begin{array}{c}60.8 \pm 10.40 \\
63(42-77)\end{array}$ & $\begin{array}{l}\text { Wilcoxon signed } \\
\text { rank test }(\mathrm{Z})=2.52\end{array}$ & 0.012 \\
\hline $\begin{array}{c}\text { Creatinine (mg/dl) } \\
\text { Mean } \pm \text { SD } \\
\text { Median (Range) }\end{array}$ & $\begin{array}{c}7.41 \pm 2.26 \\
7.2(3.4-13.7)\end{array}$ & $\begin{array}{l}7.52 \pm 1.46 \\
7.6(4.5-11)\end{array}$ & $\begin{array}{c}\text { Wilcoxon signed } \\
\text { rank test }(\mathrm{Z})=0.805\end{array}$ & 0.42 \\
\hline $\begin{array}{c}\text { Hb (g/dl) } \\
\text { Mean } \pm \text { SD } \\
\text { Median (Range) }\end{array}$ & $\begin{array}{c}9.46 \pm 0.65 \\
9.5(7.9-10.6)\end{array}$ & $\begin{array}{c}10.54 \pm 0.67 \\
10.4(9.2-12.5)\end{array}$ & $\begin{array}{c}\text { Paired t-test }= \\
-6.37\end{array}$ & $<0.001$ \\
\hline $\begin{array}{c}\text { Ca }(\mathrm{mg} / \mathrm{dl}) \\
\text { Mean } \pm \text { SD } \\
\text { Median (Range) }\end{array}$ & $\begin{array}{c}8.53 \pm 0.80 \\
8.5(6.9-10.6)\end{array}$ & $\begin{array}{c}8.70 \pm 0.69 \\
8.9(7.3-9.6)\end{array}$ & $\begin{array}{c}\text { Paired } \mathrm{t}-\text { test }= \\
-1.02\end{array}$ & 0.316 \\
\hline $\begin{array}{c}\text { Po4 }(\mathrm{mg} / \mathrm{dl}) \\
\text { Mean } \pm \text { SD } \\
\text { Median (Range) }\end{array}$ & $\begin{array}{c}5.21 \pm 1.22 \\
5.21(3.7-8.7)\end{array}$ & $\begin{array}{c}5.71 \pm 1.18 \\
5.4(3.7-8.2)\end{array}$ & $\begin{array}{c}\text { Paired } t-\text { test }= \\
-2.04\end{array}$ & 0.05 \\
\hline $\begin{array}{c}\mathrm{Na}(\mathrm{mg} / \mathrm{dl}) \\
\text { Mean } \pm \text { SD } \\
\text { Median (Range) }\end{array}$ & $\begin{array}{l}137.68 \pm 2.72 \\
137(132-143)\end{array}$ & $\begin{array}{l}137.45 \pm 2.59 \\
137(132-140)\end{array}$ & $\begin{array}{c}\text { Paired t-test }= \\
1\end{array}$ & 0.324 \\
\hline $\begin{array}{c}\text { K }(\mathbf{m g} / \mathbf{d l}) \\
\text { Mean } \pm \text { SD } \\
\text { Median (Range) }\end{array}$ & $\begin{array}{c}6.11 \pm 1.10 \\
5.9(4.50-8.30)\end{array}$ & $\begin{array}{l}6.04 \pm 1.29 \\
6.2(3.70-8)\end{array}$ & $\begin{array}{c}\text { Paired t-test }= \\
0.261\end{array}$ & 0.796 \\
\hline $\begin{array}{c}\text { PT(seconds) } \\
\text { Mean } \pm \text { SD } \\
\text { Median (Range) }\end{array}$ & $\begin{array}{c}12.1 \pm 0.66 \\
12(11-13.6)\end{array}$ & $\begin{array}{c}11.99 \pm 0.59 \\
12.2(11.5-13)\end{array}$ & $\begin{array}{c}\text { Paired t-test }= \\
1.41\end{array}$ & 0.17 \\
\hline $\begin{array}{c}\text { PTT(seconds) } \\
\text { Mean } \pm \text { SD } \\
\text { Median (Range) }\end{array}$ & $\begin{array}{l}37.01 \pm 5.21 \\
37(19-43.6)\end{array}$ & $\begin{array}{l}37.9 \pm 6.12 \\
38(19-58)\end{array}$ & $\begin{array}{c}\text { Paired t-test }= \\
-1.32\end{array}$ & 0.2 \\
\hline $\begin{array}{c}\text { CRP (mg/dl) } \\
\text { Mean } \pm \text { SD } \\
\text { Median (Range) }\end{array}$ & $\begin{array}{c}6.57 \pm 3.98 \\
5.9(0.9-15.5)\end{array}$ & $\begin{array}{c}1.8 \pm 1.2 \\
1.7(0.1-4.9)\end{array}$ & $\begin{array}{c}\text { Wilcoxon signed } \\
\text { rank test }(Z)= \\
-4.74\end{array}$ & $<0.001$ \\
\hline $\begin{array}{c}\text { Iron }(\mathbf{n g} / \mathrm{mL}) \\
\text { Mean } \pm \text { SD } \\
\text { Median (Range) }\end{array}$ & $\begin{array}{c}93.17 \pm 39.37 \\
78(50-180)\end{array}$ & $\begin{array}{c}95.57 \pm 43.46 \\
78(45-189)\end{array}$ & $\begin{array}{c}\text { Paired t-test }= \\
-0.232\end{array}$ & 0.818 \\
\hline
\end{tabular}


Table 3: Comparison between gastrointestinal symptoms in the studied children (before and after 1 month, after 2 months from combined heat killed probiotic + wheat bran administration).

\begin{tabular}{|c|c|c|c|c|c|}
\hline \multirow{2}{*}{ Variables } & Baseline & Month 1 & Month 2 & \multirow{2}{*}{ Friedman test } & \multirow{2}{*}{$P$-value } \\
\hline & $n=35$ & $n=35$ & $n=35$ & & \\
\hline \multicolumn{4}{|l|}{ Anorexia } & \multirow{2}{*}{63.43} & \multirow{2}{*}{$<0.001$} \\
\hline Median(IQR) & $4(3-4)$ & $2(2-3)$ & & & \\
\hline \multicolumn{4}{|l|}{ Nausea } & \multirow{2}{*}{50.54} & \multirow{2}{*}{$<0.001$} \\
\hline Median(IQR) & $2(2-3)$ & $2(1-2)$ & $1(1-2)$ & & \\
\hline \multicolumn{4}{|l|}{ Vomiting } & \multirow{2}{*}{53.01} & \multirow{2}{*}{$<0.001$} \\
\hline Median(IQR) & $3(2-3)$ & $2(1-2)$ & $2(1-2)$ & & \\
\hline \multicolumn{4}{|c|}{ Abdominal discomfort } & \multirow{2}{*}{55.87} & \multirow{2}{*}{$<0.001$} \\
\hline Median(IQR) & $3(3-4)$ & $2(1-3)$ & $1(1-2)$ & & \\
\hline \multicolumn{4}{|c|}{ Abdominal distension } & \multirow{2}{*}{55.22} & \multirow{2}{*}{$<0.001$} \\
\hline Median(IQR) & $3(2-3)$ & $2(1-3)$ & $1(1-1)$ & & \\
\hline \multicolumn{4}{|l|}{ Heart burn } & \multirow{2}{*}{53.91} & \multirow{2}{*}{$<0.001$} \\
\hline Median(IQR) & $3(2-4)$ & $2(1-2)$ & $1(1-2)$ & & \\
\hline \multicolumn{4}{|l|}{ Constipation } & \multirow{2}{*}{54.84} & \multirow{2}{*}{$<0.001$} \\
\hline Median(IQR) & $3(2-4)$ & $2(1-2)$ & $1(1-1)$ & & \\
\hline \multicolumn{4}{|l|}{ Diarrhea } & \multirow{2}{*}{16.75} & \multirow{2}{*}{$<0.001$} \\
\hline Median(IQR) & $1(1-2)$ & $1(1-1)$ & $1(1-1)$ & & \\
\hline \multicolumn{4}{|l|}{ Total scoring } & \multirow{2}{*}{62.64} & \multirow{2}{*}{$<0.001$} \\
\hline Median(IQR) & $22(21-24)$ & $15(14-17)$ & $10(10-11)$ & & \\
\hline
\end{tabular}

After 1 month, after 2 months from combined heat killed probiotic+wheat bran administration).

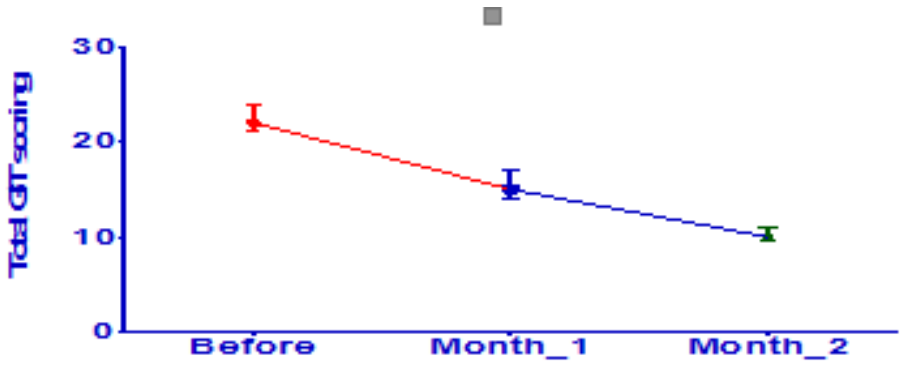

Figure 1: Line graph shows comparison between total GIT symptoms scoring (before, 1 month and 2 months after heat killed probiotic + wheat bran Low scores are better, IQR, interquartile range. 


\section{Discussion}

Uremic patients show greatly increased counts of pathogenic microorganisms in the intestine, and the absorption of proteins (and other nutrients) is hampered, so that more substrate enters the intestine; thus, more generation and absorption of uremic toxins occur, which worsens the uremic and nutritional status and accentuates gastrointestinal symptoms (GIS) [13], Moreover, intestinal bacterial overgrowth enhances bacterial translocation and production of gut-derived endotoxins, which may increase systemic inflammation [14]. In addition, in CKD patients there is an increase in $\mathrm{pH}$ that promotes the growth of aerobic bacteria in the gastrointestinal tract and the subsequent production of uremic toxins. Bifidobacteria (used as probiotics) ferment carbohydrates and produce acetic and lactic acids to acidify the intestine. Hence, these bacteria prevent the growth of aerobic microorganisms, and they normalize the altered intestinal microbiome in CKD patients [1].

Previous studies have evaluated the probiotic Lactobacillus rhamnosus GG (LGG) and its effects on inflammation in human intestinal epithelial cells, specifically the Caco-2 cell line. One study demonstrated that pretreatment with both live and heat-killed LGG downregulates the production of IL-8 when an inflammatory response is generated in this cell line following cell stimulation by tumor necrosis factor-a(TNFa) [15]. However, when an inflammatory response was not stimulated by any type of pathogenic ligand, high doses of live LGG significantly increased the production of inflammatory markers in intestinal epithelial cells, whereas heat-killed LGG only caused a slight increase [15].

This study was Open label uncontrolled clinical trial conducted on 35 children on regular hemodialysis for ESRD, we aimed to evaluate whether a combination of heat killed probiotic and wheat bran affect the presence and severity of gastrointestinal symptoms (GIS) in hemodialysis children or not. The symptoms that were included in our study are anorexia, nausea, vomiting, heart burn, gastric discomfort, abdominal distention, constipation and diarrhea. It is one of the few in this new field of research concerning probiotic and wheat bran and their effects on renal diseases.

As regard weight we found that there was no statistically significant difference between children after and before probiotic+ wheat bran, this finding agrees with a national, open, randomized, controlled intervention trial; Weight gain was marginally [16].

In our study we found that there was statistically significant change of urea while there was no change in creatinine after 2 months, this agrees with Alatriste who found statistically significant change of urea before and after using probiotic and no difference as regard creatinine [1]. RENADYL a synbiotic dietary supplement was studied in randomized clinical trials in CKD 3 and 4 and ESRD patients. Other oral therapies for removal of uremic toxins include the use of keto acids and charcoal sorbents, these trials shows that Levels of urea, uric acid, creatinine,
CRP, and the lesser known toxic metabolite arising from protein putrefaction due to gut dysbiosis in CKD, can be reduced using some specific probiotic strains with improved QOL. Other methods of toxin removal by keto acid supplementation have disadvantages in comparison to probiotic [17].

This study showed that, there was statistically significant decrease of GIT symptoms (reduction of anorexia, nausea, vomiting, abdominal distension, heart burn, constipation, diahrrea and abdominal discomfort) between children after taken combined probiotic + wheat bran administration and before, matching our results Several clinical trials have been performed to assess the efficacy of probiotic in the prevention and the treatment of gastrointestinal diseases such as diarrhea and food allergies. In antibiotic associated diarrhea main studies have reported the efficacy of oral probiotic administration for reduction of duration and frequency of the disease [18], There are several studies on frequency of defecation and gut transit time during gastroenteritis provide evidence that probiotic supplementation may have a beneficial effect on gut motility. Also Gill reported a significant reduction in total and segmental colonic transit time in subjects receiving milk fermented with $\mathrm{B}$. animal is compared with subjects given heat-treated bifidobacteria [19] [11]. Xiao S. studied the efficacy of live and killed probiotics in adult patients with chronic diarrhea and found killed probiotics were more effective than live probiotics in decreasing abdominal pain, abdominal distention and improving fecal consistency.

\section{Conclusion}

We concluded that combination of heat killed probiotic and wheat bran decreases presence and severity of gastrointestinal symptoms (GIS) in hemodialysis children, thus our results could represent an important preliminary work that justifies.

\section{Limitation of the study}

We have some limitations to our study which were mainly due to small number of available children on regular hemodialysis so we recommend to repeat the study with a control group, and divide the testing group into three groups one receive killed probiotic, one receive wheat bran and $3^{\text {rd }}$ receive combination to test the difference, in addition we recommend to test if we need to repeat the course and weather there is rebound of GIS after stoppage of medication. 


\section{References}

1- Alatriste M, P. V., Urbina Arronte, R., Gómez Espinosa, C. O., \& Espinosa Cuevas, M. D. L. Á. Effect of probiotics on human blood urea levels in patients with chronic renal failure. Nutricion hospitalaria, 2014, 29(3). 2- Dong, R., Guo, Z. Y., Ding, J. R., Zhou, Y. Y., \& Wu, H.Gastrointestinal symptoms: a comparison between patients undergoing peritoneal dialysis and hemodialysis. World Journal of Gastroenterology: WJG, 2014, 20(32), 11370.

3- Mandelbrot, D. A., \& Lazarus, J. M. Gastrointestinal complications in dialysis patients. Replacement of Renal Function by Dialysis, 1996, 1049-1058.

4- Taibi, A., \& Comelli, E. M. Practical approaches to probiotics use. Applied Physiology, Nutrition, and Metabolism, 2014, 39(8), 980-986.

5- Tako, E., Hoekenga, O. A., Kochian, L. V., \& Glahn, R. P. High Bioavailablilty Iron Maize (zea maysl.) Developed through Molecular Breeding Provides More Absorbable Iron In-vitro (caco-2) And In-vivo (gallusgallus).

Annals of Nutrition and Metabolism, 2013, 63, 252.

6- Brigide, P., \& Canniatti-Brazaca, S. G. Antinutrients and "in vitro" availability of iron in irradiated common beans (Phaseolus vulgaris).

Food Chemistry.2006, 98(1), 85-89.

7- Van Niel CW, Feudtner C, Garrison MN \& Christakis DA. Lactobacillus therapy for acute infectious diarrhea in children: A meta-analysis.

Pediatrics; 2002, 109(4): 678-684.

8- Vintiñi, E. O., \& Medina, M. S. Host immunity in the protective response to nasal immunization with a pneumococcal antigen associated to live and heat-killed Lactobacillus casei. BMC immunology, 2011, 12(1), 46.

9- Ishibashi, N., \& Yamazaki, S. Probiotics and safety. The American journal of clinical nutrition, 2001, 73(2), 465s-470s.

10- Kaila M, Isolauri E, Saxelin M, Arvilommi $\mathrm{H}$, Vesikari T. Viable versus inactivated Lactobacillus strain $\mathrm{GG}$ in acute rotavirus diarrhoea, Arch.Dis. Child, 1995, 72:51-3.
11- H. Xiao, S. D., Zhang, D. Z., Lu, H., JIANG, S. H., LIU, Y., Wang, G. S. \& WANG, G. L. Multicenter randomized controlled trial of heat-killed Lactobacillus acidophilus LB in patients with chronic diarrhea.

Journal of Digestive Diseases, 2002, 3(4), 167-171.

12- Li N, Russell W.M, Douglas-Escobar M, Mariela Lopez N, Neu J. Live and Heat-Killed Lactobacillus rhamnosus GG: Effects on proinflamatory and anti-inflammatory cytokines/ chemokines in gastrostomy-fed infant rats, Pediat. Res. 2009, 66:203-7.

13- Schepers, E., Glorieux, G., \& Vanholder, R. The gut: the forgotten organ in uremia?

Blood purification, 2010, 29(2), 130-136.

14- Kotanko, P., Carter, M., \& Levin, N. W. Intestinal bacterial microflora-a potential source of chronic inflammation in patients with chronic kidney disease. Nephrology Dialysis Transplantation, 2006, 21(8), 2057-2060.

15- Huang, F. C., \& Huang, S. C. The different effects of probiotics treatment on Salmonellainduced interleukin- 8 response in intestinal epithelia cells via PI3K/Akt and NOD2 expression.

Beneficial microbes, 2016, 7(5), 739-748.

16- Hilton E, Kolakowski P, Singer C \& Smith M. Efficacy of Lactobacillus GG as a diarrheal preventive in travellers Journal of Travel Medicine; 1997, 4: 41-43.

17- Ramezani A, \& Raj DS. (2014)The gut microbiome, kidney disease, and targeted interventions.

J Am Soc Nephrol. 2014 Apr; 25(4):657-70.

doi: 10.1681/ASN.2013080905. Epub 2013 Nov 14

18- Szymanski H, Pejcz J, Jawien M, Chmielarczyk A, Strus M, Heczko PB. Treatment of acute infectious diarrhea in infants and children with a mixture of three Lactobacillus rhamnosus strains-a randomized, double blind, placebo- controlled trial.

Aliment Pharmacol Ther, 2006, 23 (2): 247-253.

19- Gill H G, Probiotics to enhance anti-infective defences in the gastrointestinal tract Best Pract \& Res. Clinl Gastroenterol 2003, Vol. 17(5), pp. 755-773.

\section{Declaration}

\section{Ethics approval and consent to participate}

This study protocol and the consents were approved and deemed sufficient by Ethical Committee of Pediatric Department, Faculty of Medicine, Zagazig University. And informed written consent was obtained in every case from their legal guardians.

\section{Funding}

The authors declare that they didn't receive any financial support from agencies or others.

\section{Conflict of interest}

No

\section{Acknowledgements}

We would like to thank all patients and their family members for their valuable contributions to the study. 